The dynamic of landscape change at coastal area ... (Andi Gusti Tantu)

\title{
THE DYNAMIC OF LANDSCAPE CHANGE AT COAST AREA, IN LABAKKANG SUBDISTRICT PANGKEP REGENCY, SOUTH SULAWESI
}

\author{
Andi Gusti Tantu')\&(**)\#, Soemarno ${ }^{* * *}$, Nuddin Harahab ${ }^{* * *}$, and Akhmad Mustafa**) \\ ${ }^{*}$ Fisheries and Marine Science Faculty, Brawijaya University \\ **) Part of the dissertation of first author, Study Program of Fisheries and Marine Sciences \\ ${ }^{* * *}$ Successive Promoter and Co-Promoter
}

(Received 28 October 2011 ; Accepted 12 March 2012)

\begin{abstract}
Development is a changing process to improve human standard of life that strongly related to the activities of natural resource utilization. It is frequently found that these activities change the ecosystems and their resources. Eventually, these changes will give serious impacts to the environments. The most distinct environmental problems are caused by resident migration to the coastal areas, coastal developments, and land limitation. Coastal reclamation is an example of human effort to respond to the land limitation in the coastal areas as observed in coastal areas of Labakkang Subdistrict. Reclamation activity is doing along the coast of Pundata Baji Village, whereas, in other villages, cutting off of mangrove areas as an alternative land expansion is increasingly practiced by the local communities. This Research was aimed to observe the landscape change from 1980 to 2010 at coast area in Labakkang Subdistrict. Each review considers Landsat Image Map (acquired in 1980); Landsat Image Map (acquired in 1990); Landsat Image Map- 7 Enhanced Thematic Mapper Plus (ETM+) (acquired in 2000); Spot Image 4 (acquired in 2005); and Spot 4 LAPAN (acquired in 2010). Result of research indicates that at coast area of Labakkang Subdistrict in 1980 , there are 248.3 ha of mangrove vegetation, $2,756.63$ ha inundation, and 4,157.0 ha open land. In 1990, there are 234.2 ha mangrove vegetation, 2,251.63 ha embankment, 933.2 ha rice field, and 582.0 ha open land. In 2000 , there are 218.3 ha mangrove vegetation, 2,848.1 ha embankment, and 3,579.2 ha rice field. In 2005, it has 121.4 ha mangrove vegetation, 3,762.6 ha embankment, and 2,306.2 ha rice field. In 2010, it is found 48.9 ha mangrove vegetation, 5,029.35 ha embankment, and 749.98 ha rice field.
\end{abstract}

KEYWORDS: coast, SIG, landscape

\section{INTRODUCTION}

The coast and marine resources, including fishery resource, are the great asset to mobilize the economic growth. However, the sustainability of this capacity is obstructed either by the reverse activity against strategic function and the bright prospect of this resource, or by the human and natural barriers resulting in the less optimum and less sustainable development (Dahuri et al., 2001).

The landscape change occurred in the coast environment is mainly due to human behavior which is always increasing their social-economical status. The improvement of

\# Corresponding author. Fisheries and Marine Sciences Faculty, Brawijaya University Jl. Veteran, Malang 65145, Indonesia. Tel.: + 62341553512

E-mail address: agustitantu@yahoo.com 
this status is driven by the poverty factor in the human life (Efendi et al., 2005).

The development represents a change process to improve the human subsistence, but it is still not separated from the activity of using natural resource. This activity always involves the change of ecosystem and surely, natural source. Any change must give obvious impact on life environment. In the coast area, the most apparent environmental issue is related to the land use. Three causal factors are found: (1) the increasing population growth, either naturally (by birth) or the migration from other places; (2) the development which is dominant at coast area; and (3) land limitation. Coast reclamation, as human activity to answer the land limitation issue at coast area, is occurred at the coast area of Labakkang Subdistrict. The reclamation activity is conducted along coast area at Pundata Baji Village. Other village must experience the logging in the mangrove area as the alternative for embankment area extension. The logging, however, tends to increase for recent years (Collini, 2008).

The developed area is then used for the facility and residence. Coast reclamation, in fact, fails to be well implemented. Therefore, great concern is given to the negative impact such as the float materials causing the shallow of waters. This can threat coast ecosystem. Taking this into background, the research is conducted and entitled with "The Dynamic of Landscape Change at Coast Area, in Labakkang Subdistrict, Pangkep Regency, South Sulawesi". The research was aimed to observe understanding the landscape change from 1980 to 2010 at coast area in Labakkang Subdistrict, Pangkep Regency, South Sulawesi.

\section{MATERIALS AND METHODS}

\section{Description of Area and Timing of Research}

The coast area of Labakkang Subdistrict geographically remains in the $119^{\circ} 28^{\prime} 57.63^{\prime \prime}$ east longitude throughout $119^{\circ} 33^{\prime} 30.27^{\prime \prime}$ east longitude, and $4^{\circ} 43^{\prime} 03.30^{\prime \prime}$ south latitude throughout $4^{\circ} 47^{\prime} 26.93^{\prime \prime}$ south latitude. The coast area at Labakkang Subdistrict has \pm 3000 ha, including four villages in boundary with Pundata Baji Village, Borimasunggu Village, Bontomanai Village, and Kanaungan Village (Labakkang in Numbers, 2009). Research begins from June to August 2010, in the Labakkang
Subdistrict, Pangkep Regency, So uth Sulawesi. It involves the collection of primary and secondary data, the development of geographic information system, and the development of model for analysis.

\section{Materials}

The secondary data are collected to give input into the geographic information system, either in the format of spatial data or attribute data. Data represent the image maps, consisting of Lansat Image Map (acquired in 1980); Lansat Image Map (acquired in 1990); Lansat Image Map- 7 Enhanced Thematic Mapper Plus $(E T M+)$ (acquired in 2000); Spot Image 4 (acquired in 2005); and Spot Image 4 Lapan (acquired in 2010). In addition, basic map is also used such as Earth Shape Map, especially Sheet 2011- 31 (Pangkajene Sheet) and 201133 (Segeri Sheet). The administration map of Pangkep Regency has been used as the analysis base.

\section{Methods}

The methodologies used in this research include: the spatial analysis with ArcView 3.3 and ArcGIS 9.3; multi- criteria analysis for the appearance and mapping with ARCMAPÒ version 9.3; multi- temporal image analysis with ER MAPPER $^{\mathrm{TM}}$.

\section{The Determination of Cover Wide/ Land Use}

The determination of cover wide/ land used was implemented by using the data of Spot Image 4 acquired in 2010, and the data of field survey result. The image data is functioning as the base data to see the whole landscape in the reviewed area (research area). The survey result becomes the verified material to compare with the information from the image data.

The image used was the image with geometric correction, radiometric correction, and replicated rectification to follow local coordinate system. The improvement of Landsat Image quality has been made with by improving the image sharpness and increasing spatial resolution.

The image sharpness conducted by modifying the contrast of image data was done by the support of Er Mapper 7.1 (Danoedero, 2004a). In the early process before research, classification was conducted to obtain gen- 
The dynamic of landscape change at coastal area ... (Andi Gusti Tantu)

eral information about the variation of coverage/ land use at research location. It also gives the base understanding to estimate the type, number and distribution of research area (region of interest/ Rol) which were the sample to be taken during classification after research. The classification was empowered by local knowledge about the coverage, land use and land shape characteristics in research location based on the information of Indonesia Republic Map or the other spatial information.

The next step was using this early classification map to take the pixel sample from the area to ensure the type. The sampling was surely conducted based on the conceptual understanding about spectral response pattern of each object type in the spectral space (Danoedoro, 2004b; Jensen, 2005). To increase the accuracy of the sampling over each object, the supporting data were used such as earth shape map and the field information with acknowledgeable coordinate. The pixel samples, with the total of 100 pixels in the minimum area, were stored in the form of Rol. The minimum of 3 Rol were taken from each object type. The flow diagram was used to determine the wide of each coverage/land use in Labakkang Subdistrict, Pangkep Regency, South Sulawesi, as shown in Figure 1.

The final result of classification is the map of embankment distribution and its land use around the embankment. The final map of coast land use will be verified with the field data to reduce the error in the classification. The land use around the embankment is used to predict the potential of embankment land if the land should be converted into embankment. The possibility of this land conversion will be predicted by involving some key variables of embankment development, such as land elevation and tide- ebb range.

\section{RESULT AND DISCUSSION}

\section{The Landscape Change}

\section{The Landscape in 1980}

In the photograph of Landsat Satellite Image (acquired in 1980), it is shown that the landscape at coast area in Labakkang Subdis-

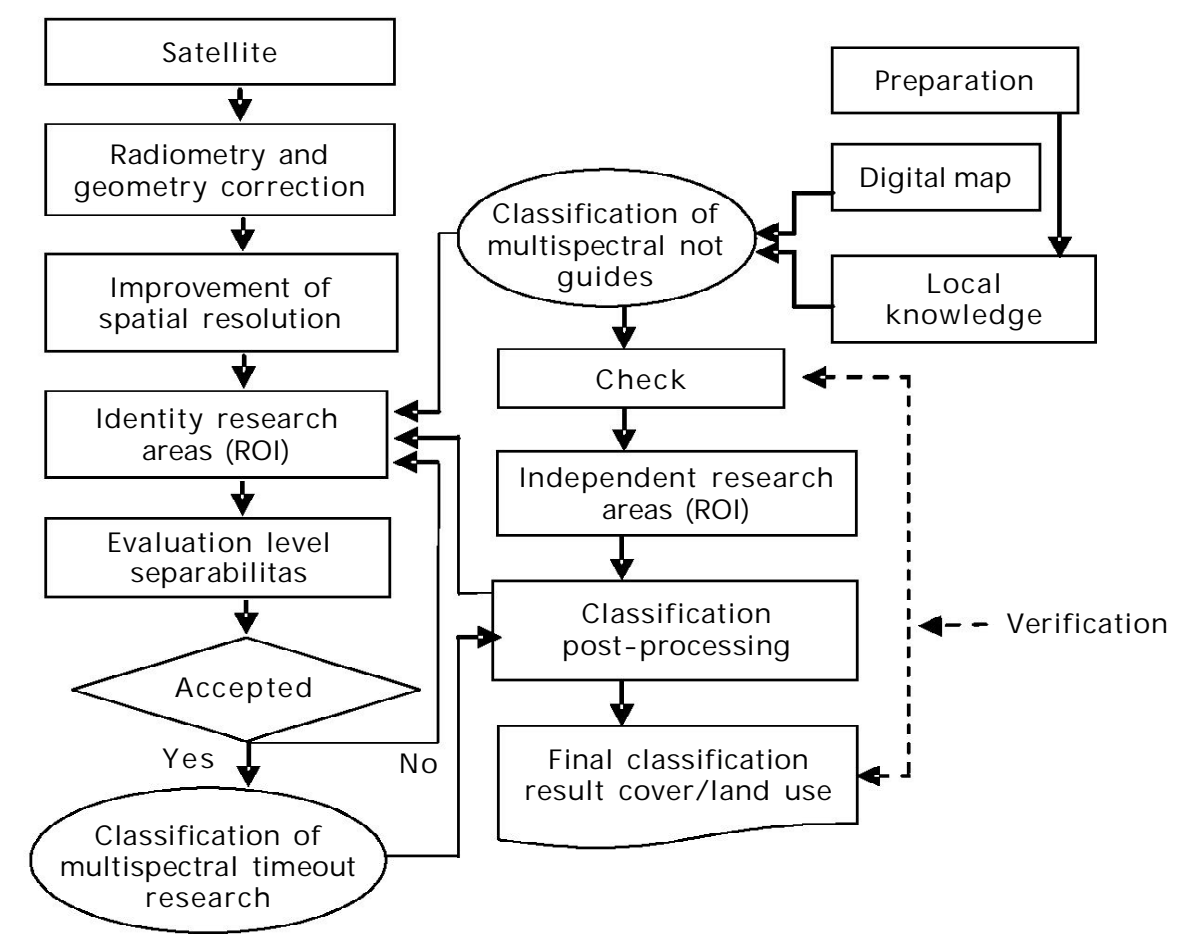

Figure 1. The flow chart in determining the area of each cover/land use in District Labakkang, District Pangkep 
trict in 1980 involves river, inundation, mangrove, open land, and vegetation. Based on the area wide measurement, in 1980, there are 248.3 ha of mangrove vegetation, $2,756.63$ ha inundation, and 4,157.0 ha open land. In detail, the landscape wide of Labakkang Subdistrict in 1980 is shown in Figure 2.

\section{The Landscape in 1990}

The photograph of Landsat Satellite Image (acquired in 1990) shows that the landscape at coast area in Labakkang Subdistrict in 1990 involves embankment, river, rice field, mangrove, open land, and vegetation. Based on the area wide measurement, in 1990, there are 234.2 ha mangrove vegetation, 2,251.63 ha embankment, 933.2 ha rice field, and 582.0 ha open land. In detail, the landscape wide of Labakkang Subdistrict in 1990 is shown in Figure 3.

\section{The Landscape in 2000}

The photograph of Landsat Satellite Image7 Enhanced Thematic Mapper Plus (ETM+), (acquired in 2000) shows that the landscape of coast area in Labakkang Subdistrict in 2000 includes residence, embankment, river, mangrove, and vegetation. Based on the area wide measurement, in 2000, there are 218.3 ha mangrove vegetation, 2,848.1 ha embankment, and 3,579.2 ha rice field. In detail, the landscape wide of Labakkang Subdistrict in 2000 is shown in Figure 4.

\section{The Landscape in 2005}

The photograph Spot Image 4 Lapan (acquired in 2005) indicates that the landscape at coast area in Labakkang Subdistrict in 2005 includes residence, embankment, river, mangrove, rice field and vegetation. Based on the area wide measurement, in 2005, it has 121.4 ha mangrove vegetation, 3,762.6 ha embankment, and 2,306.2 ha rice field. In detail, the landscape wide of Labakkang Subdistrict in 2005 is shown in Figure 5.

\section{The Landscape in 2010}

The photograph of Spot Image 4 Lapan (acquired in 2010) indicates that the landscape at coast area in Labakkang Subdistrict in 2010 comprises to residence, embankment, river, mangrove, and vegetation.

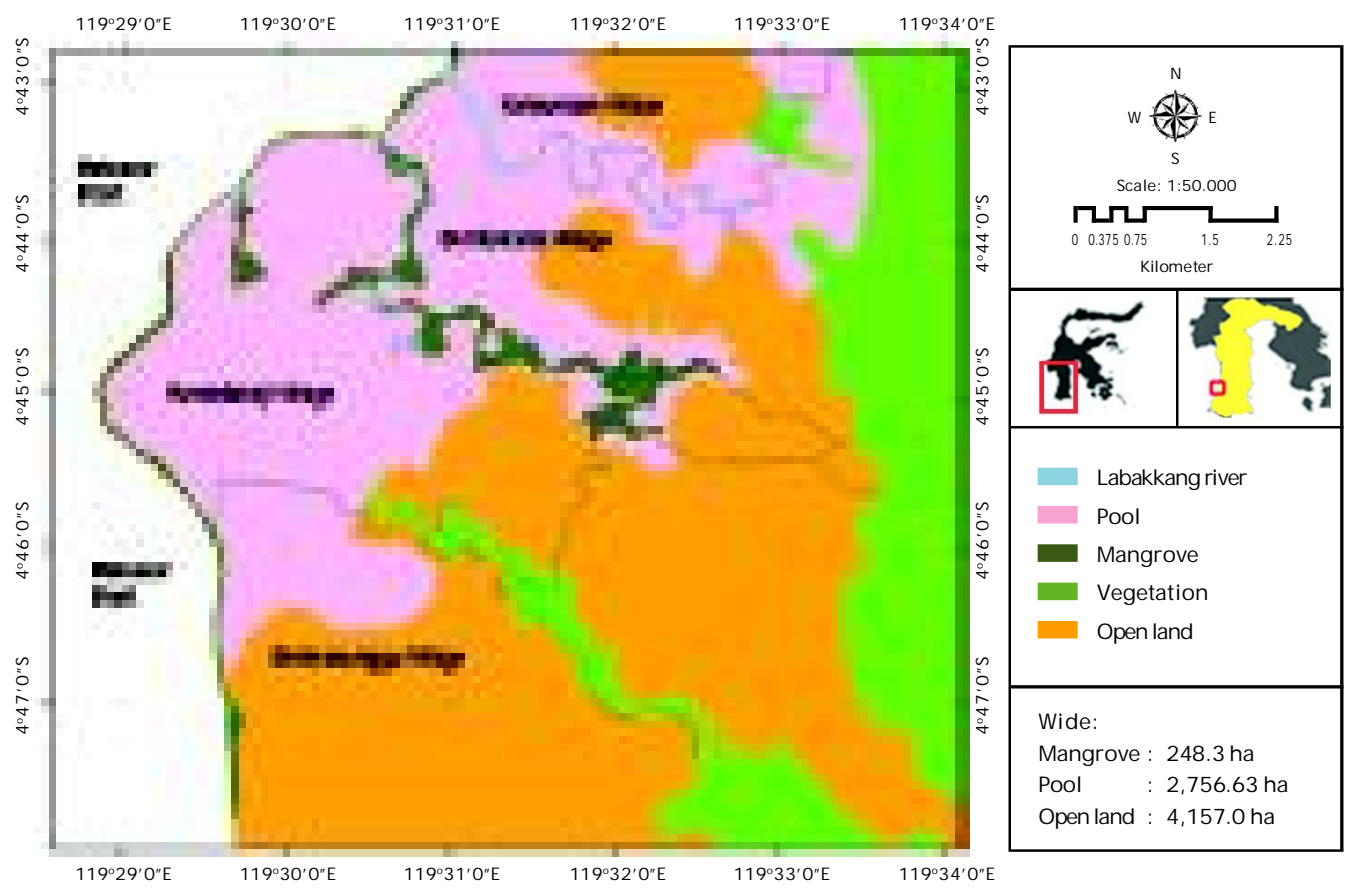

Figure 2. The landscape of Labakkang Subdistrict, based on Landsat Satellite Image (acquired in 1980) 
The dynamic of landscape change at coastal area ... (Andi Gusti Tantu)

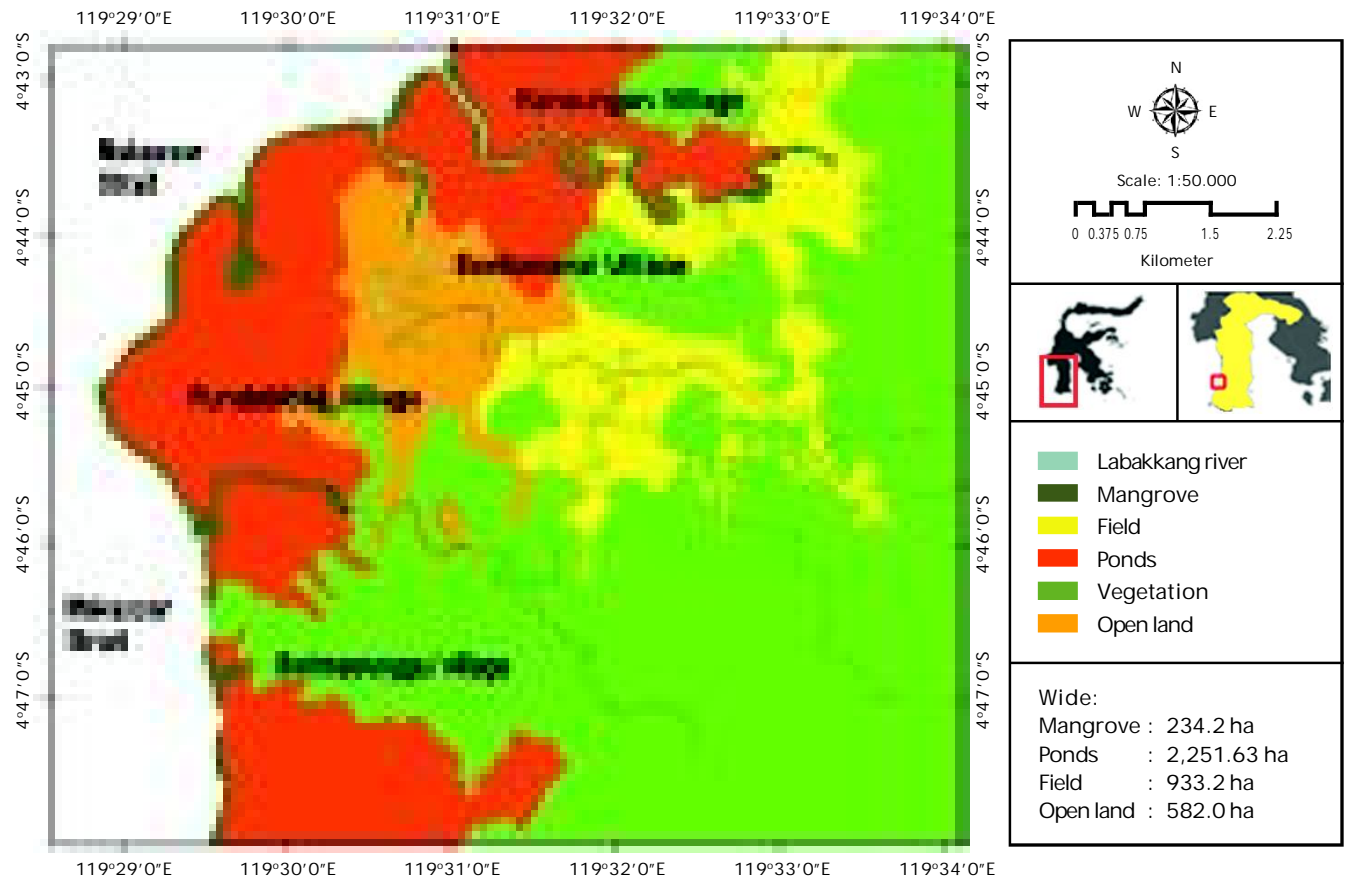

Figure 3. The landscape of Labakkang Subdistrict, based on Landsat Satellite Image (acquired in 1990)

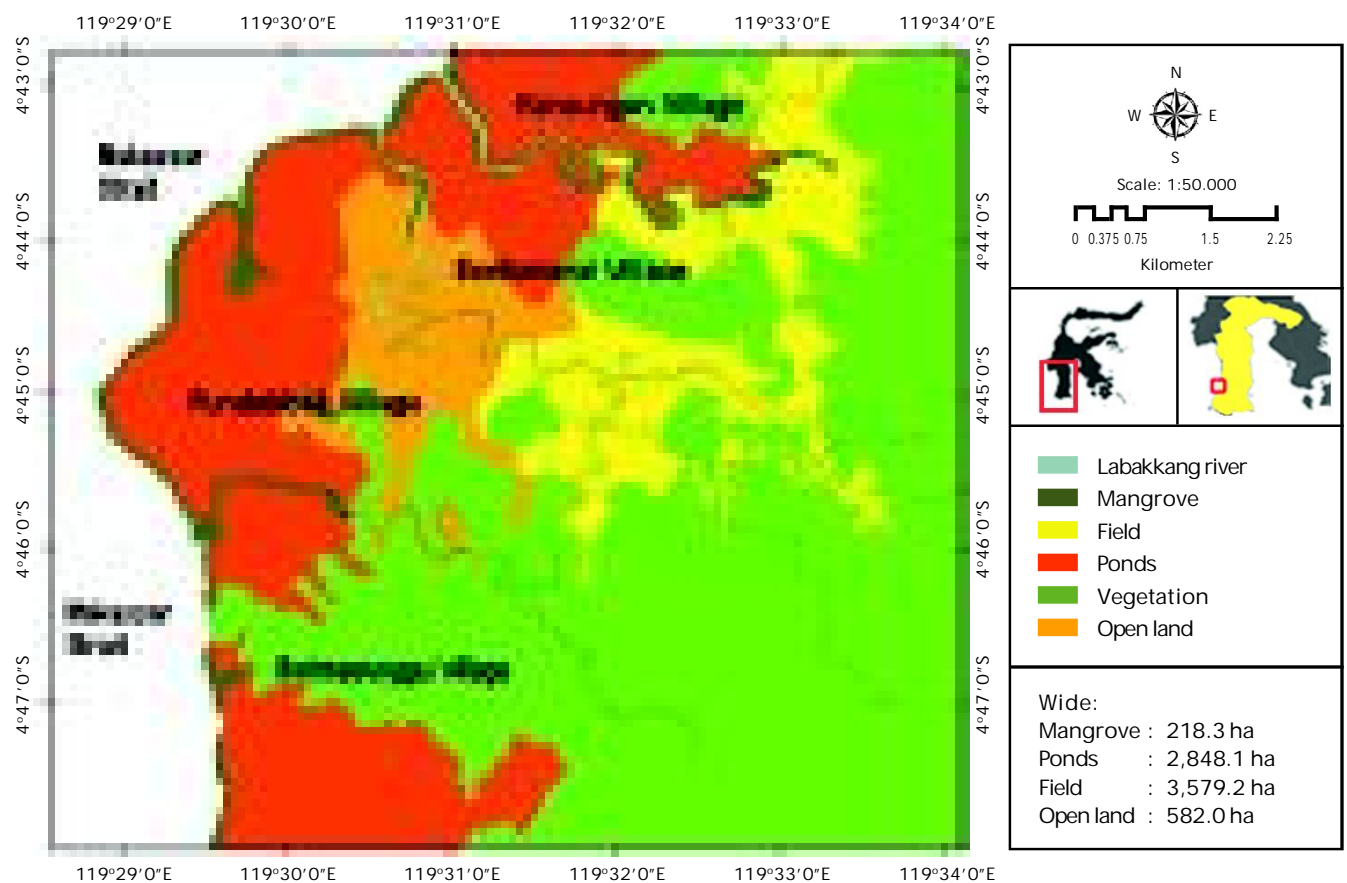

Figure 4. The landscape of Labakkang Subdistrict, based on the photograph of Landsat Satellite Image- 7 Enhanced Thematic Mapper Plus (ETM+) (acquired in 2000) 
Indonesian Aquaculture Journal Vol.7 No.1, 2012

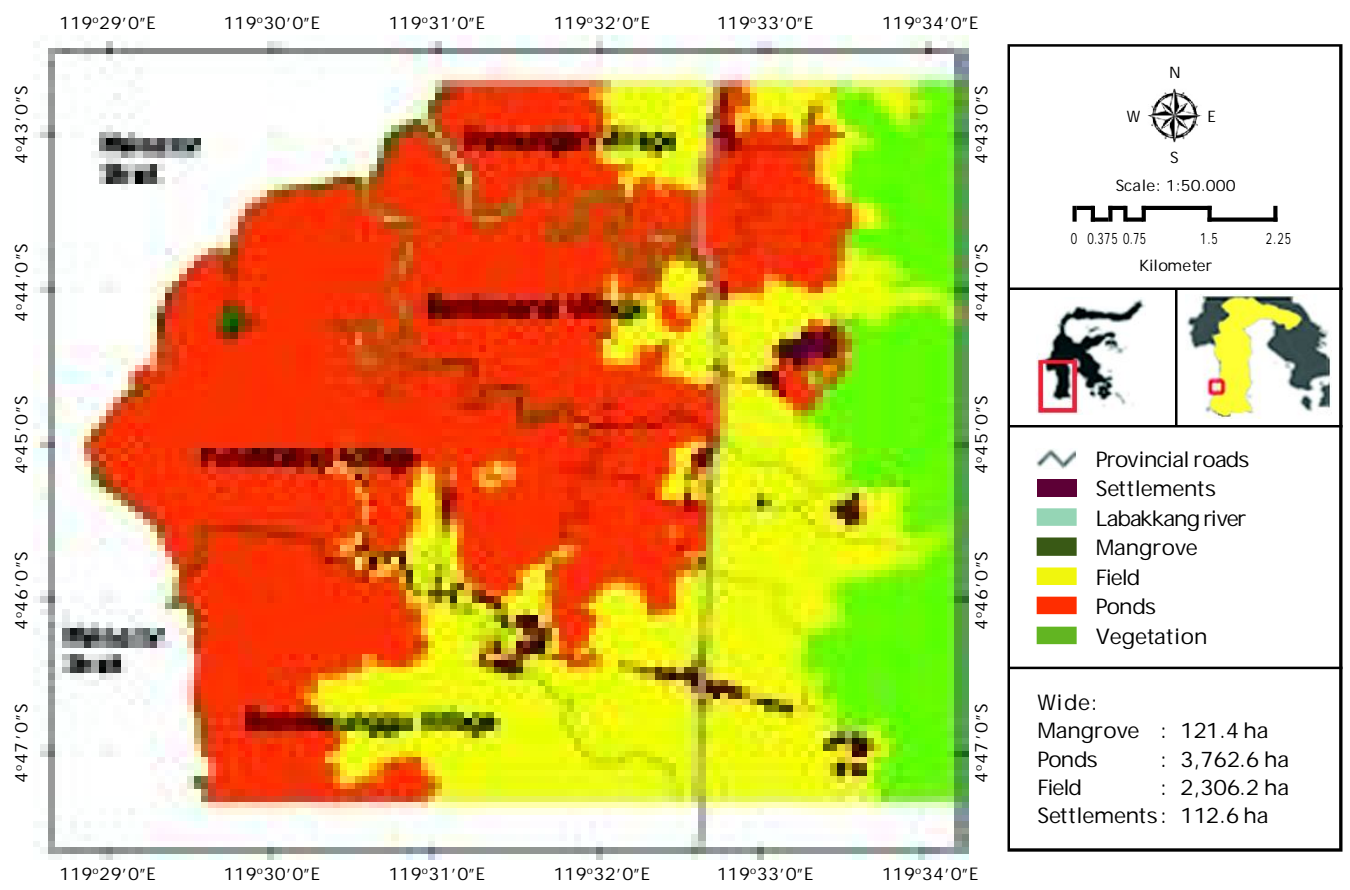

Figure 5. The landscape of Labakkang Subdistrict, on the photograph of Spot Image 4 Lapan (acquired in 2005)

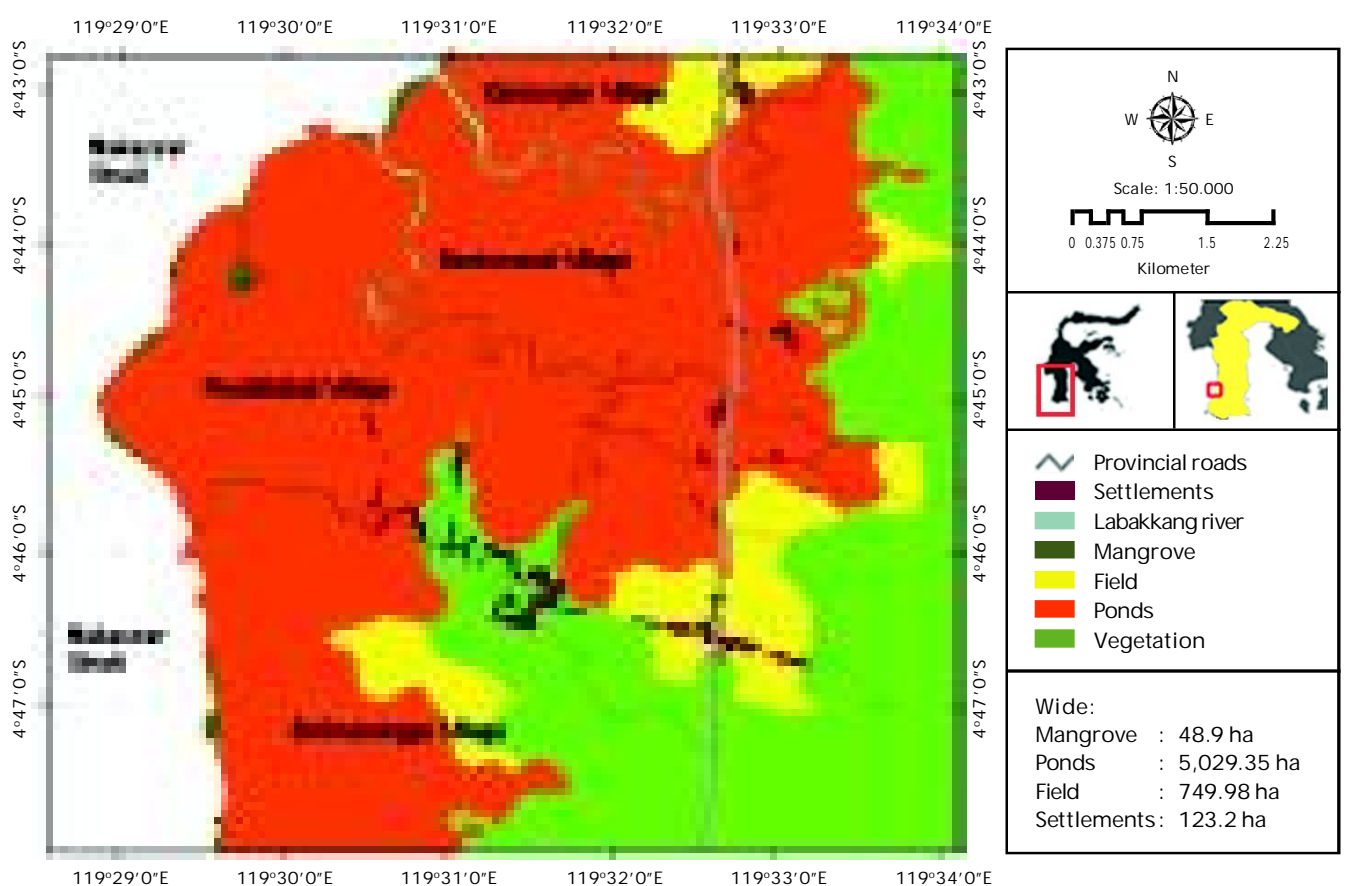

Figure 6. The landscape of Labakkang Subdistrict, based on the photograph of Spot Image 4 Lapan (acquired in 2010) 
The dynamic of landscape change at coastal area ... (Andi Gusti Tantu)

Based on the area wide measurement, in 2010 , it is found 48.9 ha mangrove vegetation, 5,029.35 ha embankment, and 749.98 ha rice field. In detail, the landscape wide of Labakkang Subdistrict in 2010 is shown in Figure 6.

\section{The Dynamic of Landscape Change}

Based on the maps shown in the Landsat Satellite Image in 1980 (Figure 2); Landsat Satellite Image in 1990 (Figure 3); Lansat- 7 Enhanced Thematic Mapper Plus (ETM+), in 2000 (Figure 4); Spot Image 4 Lapan, in 2005 (Figure 5); and Spot Image 4 Lapan, in 2010 (Figure 6), some types of land use are identified, such as mangrove, inundation, vegetation, embankment, rice field, river, and residence. In this research, the measurement of each land use wide is only concerned with the wide of mangrove, embankment, and rice field to understand the dynamic of change in each land use at different time period. In detail, the wide of land use is shown in Table 1.

From Figure 2 and Table 1, The Map Landsat Satellite Image in 1980 indicates that the coast area of Labakkang Subdistrict is commonly covered by water inundation, mangrove, and openland. The mangrove wide is $284.4 \mathrm{ha}$, consisting of great trees. The mangrove vegetation in this area is dominated by Avicenna marina, Nypa fruticans, Rhizophora stylosa, Rhizophora mucronata, Rhizophora apiculata, Hibiscus tiliaceus and Sonneratia albs, which are mostly found in coast line, salty swamp, and river bank.

The land coverage remains in the form of $2,756.6$ ha inundation. The picture is taken during rainy season. Therefore, it is difficult in the picture to distinguish the embankment dike, or to differentiate between embankment and rice field. Based on the information of the land owners, in 1980, the embankment dike is not greater than recent dike. Usually, the dike is used only for the border of land ownership. The cultivation pattern excludes the seedling, but expects that the seed penetrates into the embankment during high tide, and then followed by the closure of water entry gate.

Other land coverage dominating the area includes bush, meadow, less productive rice field, and vegetation, which are categorized as the open land, with $4,157.1$ ha wide. The land wide coverage for the research area is 7,200 ha, comprising to open land, rice field, inundated land, and mangrove. The development of land use at Labakkang Subdistrict is continually undergone in consistent to the age demand and population growth.

In the 10-years time period, in 1990, The Map of Landsat Satellite Image acquired in 1990 (Figure 3 ) and (Table 1) indicates the meaningful change of land use. The mangrove wide becomes 234.2 ha, meaning that the wide reduces by 50.2 ha or $17.66 \%$ The change is evident due to the infiltration by the mobile inhabitants without land to use the area for embankment (Karthik et al., 2005). The increase of embankment wide is directed into the use of open land, rice field, and swamp. Therefore, the embankment wide in 1990 reaches 2,251.4 ha.

The embankment land extension seems involving the use of open land and vegetation with the possibility of becoming embankment. The extension of rice field land also considers the open land and vegetation. Embankment

Table 1. The land use and land wide of each image map in 1980, 1990, 2000, 2005, and 2010 in Labakkang Village

\begin{tabular}{lrrrrr}
\hline \multirow{2}{*}{ Type of use } & \multicolumn{5}{c}{ Year (ha) } \\
\cline { 2 - 6 } & $\mathbf{1 9 8 0}$ & $\mathbf{1 9 9 0}$ & $\mathbf{2 0 0 0}$ & $\mathbf{2 0 0 5}$ & $\mathbf{2 0 1 0}$ \\
\hline Mangrove & 284.4 & 234.2 & 218.3 & 121.4 & 49.0 \\
Inundation & $2,756.6$ & & & & \\
Embankment & & $2,251.4$ & $2,848.1$ & $3,762.6$ & $5,029.3$ \\
Rice field & & 933.2 & $3,579.2$ & $2,306.2$ & 749.9 \\
Open land & $4,157.1$ & 582.3 & & & \\
\hline
\end{tabular}

Source: Result of analysis (2010) 
extension may not consider the use of mangrove because the mangrove wide already reduces to narrower rate than ten years before. The use of mangrove land is usually found along the river which is flowed into embankment and residence area. Land availability seems good enough. The subsistence is still dominated by the rice field farmers, and therefore, the embankment work is being the side job.

In 1990, the clear difference is seen between mangrove, embankment, rice field, open land, and vegetation. The open land with 582.3 ha wide is unprocessed land because it is a swamp with water inundation. Therefore, it is difficult to convert it into embankment due to its high depth level.

The photograph of Landsat Satellite Image7 Enhanced Thematic Mapper Plus (ETM+), (acquired in 2000), (Figure 4) and (Table 1), the great increase of embankment wide is by 593.7 ha or $26.4 \%$ which is reaching to $2,848.1$ ha. The rice field also increases by 2,586 ha or $277.1 \%$ which is reaching to $3,579.2$ ha. However, mangrove reduces by 15.9 ha or $6.79 \%$ The increasing embankment wide is directed toward the use of open land. This open land is swamps but with sedimentation due to erosion. It accumulates the materials brought by the water stream during flood. Therefore, this land has similar height to the embankment. In addition of the use of open land, the extension also includes vegetation. The conversion into embankment also involves rice field with sea water intrusion.

The increase of rice field wide attains to 3,579 ha. It is occurred due to the increasing access of technical irrigation such that the less functional land and those categorized as vegetation will change into productive rice field (Karthik et al., 2005).

The photograph of Spot Image 4 Lapan in 2005, (Figure 5) and (Table 1), indicates the increase of embankment wide from 2,848.1 ha in 2000 to $3,762.6$ ha in 2005 or the great increase of embankment wide by 940.5 ha in 5 years, or $188.1 \mathrm{ha} /$ year. In contrast, the reduction of rice field wide from $3,579.2$ ha to $2,306.2$ ha is experienced, or the reduction of rice field wide for 1,273 ha is occurred. It means that the rice field is the greatest land use at the coast area of Labakkang Subdistrict to be converted into embankment.
The reduction of rice field is also evident due to its conversion into residence (Barnsley et al., 2001). The remaining of the land which is then converted into embankment emanates from other land use at the coast area of Labakkang Subdistrict, such as mangrove and vegetation. It is reported that the mangrove logging at coast area is increased to convert the mangrove land into embankment land (Barnsley et al., 2001). In Figure 5, in the 5 years time period, the mangrove wide reduces by 96.9 ha, mainly from 218.3 ha in 2000 to 121.4 ha in 2005 , or reduces by $44.38 \%$

With respect to the photograph of Spot Image 4 Lapan (acquired in 2010) (Figure 6) and (Table 1), the embankment wide is increased from 3,762.6 ha in 2005 to 5,029.35 in 2010 , or the embankment wide is increased for $1,266.65$ ha in 5 years or 253.3 ha/ year. However, the rice field wide at the coast area of Labakkang Subdistrict is reduced, precisely from 2,306.2 ha to 749.9 ha, or the rice field wide is reduced for $1.556,3$ ha. It means that the rice field is the greatest land use at the coast area of Labakkang Subdistrict to be converted into embankment. The mangrove land wide is reduced from 121.4 ha in 2005 to 49 ha in 2010 , meaning that it reduces for 72.4 ha or $59.6 \%$ find that the embankment cultivators at Pangkep Regency already have planted mangrove in the river bank or in the coast area. However, when the mangrove is established on the land, the cultivators cut the mangrove to extend their embankment land. The worse is that the cultivators cut greater number of mangrove just for the embankment extension (Choudury, 2000).

\section{CONCLUSION}

Result of analysis of landscape change in 1980, 1990, 2000, 2005, and 2010 indicates that the land coverage wide is changed. The characteristic is as follows. In 1980, there are 248.3 ha of mangrove vegetation, $2,756.63$ ha inundation, and 4,157.0 ha open land. In 1990, there are 234.2 ha mangrove vegetation, 2,251.63 ha embankment, 933.2 ha rice field, and 582.0 ha open land. In 2000, there are 218.3 ha mangrove vegetation, $2,848.1$ ha embankment, and 3,579.2 ha rice field. In 2005, it has 121.4 ha mangrove vegetation, 3,762.6 ha embankment, and 2,306.2 ha rice field. In 2010 , it is found 48.9 ha mangrove vegetation, 5,029.35 ha embankment, and 749.98 ha rice field. 
The dynamic of landscape change at coastal area ... (Andi Gusti Tantu)

\section{REFERENCES}

Barnsley, M.J., Møller-Jensen, L., \& Barr, S.L. 2001. Inferring urban land use by spatial and structural pattern recognition. In: J.P. Donnay, M.J. Barnsley, and P.A. Longley (Eds.), Remote Sensing and Urban Analysis. Taylor and Francis, London, p. 225- 242.

Collini, K. 2008. "Coastal Community Resilience: An Evaluation of Resilience as a Potential Performance Measure of the Coastal Zone Management Act." Written for NOAA Office of Ocean and Coastal Resource Management in collaboration with the Coastal States Organization, $352 \mathrm{pp}$.

Choudury, \&Junaid, K. 2000. Sustainable Management of Coastal Mangrove Forest Development And Social Need In Mangrove and Other Coastal Forest http:// www.eepsea.org/publications/research, p. 267- 286.

Dahuri, R., Rais, J., Putra Ginting, S., \& Sitepu, M.J. 2001. Coastal Resources Management and the Integrated Ocean. Jakarta: PT. Pradnya Paramita.

Danoedoro, P. 2004a. Classification of land cover in detail: the experience with landsat ETM and QuickBird. In: Danoedoro, P. (ed.), Sains Informasi Geografis: From the Image Acquisition and Analysis to Mapping and Spatial Modeling. Department of Car- tography and Remote Sensing, Faculty of Geography, University of Gadjah Mada, Yogyakarta.

Danoedoro, P. 2004b. Information multidimensional land use: Toward a classification system of land use multipurpose regional planning and environmental modeling. In: Danoedero, P. (ed.), Geographic Information Science: Data Acquisition and Analysis Image to Mapping and Spatial Modeling. Department of Cartography and Remote Sensing, Faculty of Geography, University of Gadjah Mada, Yogyakara.

Jensen, J.R. 2005. Introductory Digital Image Processing: a Remote Sensing Perspective. Third edition. Pearson Prentice Hall, Upper Saddle, NJ.

Karthik, M., Suri, J., Saharan, N., \& Biradar, R.S. 2005. Brackish Water Aquaculture Site Selection in Palghar Taluk, Thane district of Maharashtra, India, Using the Techniques of Remote Sensing and Geographical Information System. Aquacultural Engineering, 32: 285- 302.

Efendy, M., Haluan, J., Monintja, D.R., \&Purwanto, J. 2005. Design of Information System Utilization of Fishery Resources in Coastal Resources Management and Integrated Ocean. Graduate Forum VOT. 28 No.3 shock, 2005: 273- 283. 